\title{
Anti-viral activity of Zingiber officinale (Ginger) ingredients against the Chikungunya virus
}

\author{
Sulochana Kaushik ${ }^{2}$ Ginni Jangra ${ }^{1}$ - Vaibhav Kundu ${ }^{3}$ Jaya Parkash Yadav $^{2}$. \\ Samander Kaushik ${ }^{1}$ (D)
}

Received: 25 December 2019/Accepted: 20 April 2020/Published online: 5 May 2020

(C) Indian Virological Society 2020

\begin{abstract}
Chikungunya is one of the highly infectious viral disease without vaccine and anti-viral. Aim of present study is to check the anti-chikungunya activities of Zingiber officinale (Ginger) in the animal cell culture model. The medicinal plant extract was prepared from $Z$. officinale rhizome. Median tissue culture infective dose $\left(\mathrm{TCID}_{50}\right)$ of Chikungunya virus (CHIKV) and Maximum non-toxic dose (MNTD) of Z. officinale extract was determined in Vero cell-line on the basis of cell viability followed by MTT assay. In vitro anti-chikungunya activity was performed in Vero cell-line with MNTD and half of MNTD of Z. officinale medicinal plant extract. The anti-viral effect of $Z$. officinale was studied by observing the cytopathic effects and cell viability measured by MTT assay. Maximum non-toxic dose of $Z$. officinale plant extract was found $62.5 \mu \mathrm{g} / \mathrm{ml}$. During anti-chikungunya experimentation, cell viability increased to $51.05 \%$ and $35.10 \%$, when Vero cells were pre-treated with MNTD and half of MNTD of $Z$. officinale extract respectively. Similarly, in co-treatment, when MNTD, half of MNTD of Z. officinale and Median tissue culture infective dose CHIKV were inoculated simultaneously, then the viability of Vero cell-line was increases by $52.90 \%$ and $49.02 \%$ respectively. The rhizome extracts of $Z$. officinale have high potential to treat CHIKV. Medicinal plants and their metabolites are most
\end{abstract}

Samander Kaushik

samanderkaushik@gmail.com

1 Centre for Biotechnology, Maharshi Dayanand University, Rohtak, Hr, India

2 Department of Genetics, Maharshi Dayanand University, Rohtak, Hr, India

3 Department of Nanotechnology, Amity University, Noida, U. $\mathrm{P}$, India important sources of antimicrobial and can be utilized for the development of new drugs. In view of the rapid expansion of CHIKV at the global level, there is an urgent need to develop newer anti-chikungunya drugs.

Keywords Zingiber officinale (ginger) · Chikungunya virus · Animal cell culture · Medicinal plants · Cytotoxicity

\section{Introduction}

Chikungunya is a vector born arthritogenic febrile illness caused by an alphavirus of the Togaviridae family. Chikungunya virus (CHIKV) was the first time isolated from a dengue-like epidemic in Tanzania [1]. CHIKV is transmitted by Aedes mosquitoes, which are also responsible for spreading Dengue and Zika viruses [2]. Apart from the usual clinical manifestations of mosquito-borne infection, CHIKV infected individuals endure extreme joint pain due to over secretion of cytokines that may last for months to years. The rapid expansion of CHIKV on a global scale was facilitated by an ecologically plastic mosquito Aedes albopictus [3, 4]. Comparatively, A. albopictus is more diverse and ecologically stable than $A$. aegypti, therefore it is found in dominant position in Kenya, Comoros, La' Reunion (France), India, Southeast Asia, Seychelles, Mauritius, Madagascar and Mayotte CHIKV outbreaks [5]. In the present scenario, The National Institute of Allergy and Infectious disease (NIAID), USA re-categorized CHIKV into priority group B pathogen of their Emerging Infectious Disease [6]. Complications associated with CHIKV infections include Guillain-Barré syndrome, Encephalomyelopathy, Neonatal Hypotonia, Uveitis, Retinitis, Optic Neuritis, Myelopathy and Myelitis [7]. So far, the CHIKV control measure 
includes the prevention of infection only. There is no vaccine and antiviral for CHIKV, therefore a specific, economical and effective antiviral molecule desire.

Available synthetic compounds have little effect on CHIKV but show strong side effects including an increase in joint pain limit their utility [8]. On the other hand, antiviral molecules from natural resources can be more promising anti-CHIKV activity [9-11]. Plant metabolites can be more safe, effective and economical, especially for vulnerable areas that have limited resources [12]. Medicinal plants have great potential for therapeutic purposes. The present study focuses on the antiviral properties of $Z$. officinale which is an herbaceous Asian plant. Apart from its anti-inflammatory, anti-nausea, anticarcinogenic activity, rhizomes of $Z$. officinale are rich in metabolites with potential antiviral properties [13-15].

\section{Materials and methods}

\section{Reagents and chemicals}

Cell growth media (Dulbecco's Modified Eagle's Medium (DMEM) with penicillin and streptomycin sodium bicarbonate and 10\% heat-inactivated FBS), Phosphate Buffer Saline (PBS) (Hi-media laboratories), Thiazolyl Blue Tetrazolium Bromide (MTT) (Hi-media laboratories), cell culture tested DMSO, Infection media (DMEM supplemented with penicillin and streptomycin sodium bicarbonate and 2\% heat-inactivated FBS), 1\% Trypsin Phosphate Versene Glucose (TPVG) (Hi-media laboratories).

\section{Preparation of plant extract}

Fresh clean, rhizomes of Z. officinale (Specimen voucher number Ref. No NISCAIR/ RHMD/2019/3555-56-I) were diced into fine pieces, air-dried and ground to a fine powder. The Z. officinale powder was added into sterile doubledistilled water in a 1:10 ratio then boiled for the $20 \mathrm{~min}$. Zingiber officinale aqueous plant extract was prepared and filtered through Whatman filter paper and the filtrate was characterized with the help of FTIR. The plant extract was stored in a refrigerator after proper labeling.

\section{Cell and virus culture}

Vero cell-line was obtained from the All India Institute of Medical Science (AIIMS) New Delhi. Vero cell-line was cultured in the DMEM growth medium and incubated in a humid atmosphere at $37{ }^{\circ} \mathrm{C}$ in a $\mathrm{CO}_{2}$ incubator. Vero cells were observed daily for their growth and media was changed after 3-4 days of incubation. Healthy Vero cells were added into the 96- well tissue culture plate and incubated until confluent. CHIKV used in this study belongs to the Indian Ocean lineage (IOL) genotype and propagated in Vero cells supplemented with infection medium. Cells were observed daily for the Cytopathic effect (CPE). Cells were harvested after CPE and stored at $-80{ }^{\circ} \mathrm{C}$ until used.

\section{Cytotoxicity evaluation}

Cytotoxicity assay was performed for Z. Officinale plant extract. Stock solutions of $Z$. officinale extract were prepared in cell growth media at concentrations of $2 \mathrm{mg} / \mathrm{ml}$. The assay was performed in duplicates with two-fold serial dilutions of plant extract. Negative control (untreated cells) was also included in the assay. Plates were incubated at $37{ }^{\circ} \mathrm{C}$ in a $\mathrm{CO}_{2}$ incubator for $48 \mathrm{~h}$. Cell viability was checked by performing the MTT assay. Briefly, $10 \mu \mathrm{l}$ of 3(4,5-Dimethylthiazol 2 yl)-2, 5 diphenyl tetrazolium bromide (MTT) of salt solution was added into each well of the plate. The plate was carefully incubated for $4 \mathrm{~h}$. After the proper incubation period, MTT solution removed carefully and $200 \mu \mathrm{l}$ DMSO/well was added. Absorbance was measured at $595 \mathrm{~nm}$ with the help of a microplate reader (Bio-Rad, USA). Percentage of cell viability was calculated by using the following formula;

Cell viability $(\%)=\left[\frac{\left(\mathrm{A}_{\text {sample }}-\mathrm{A}_{\text {blank }}\right)}{\left(\mathrm{A}_{\text {control }}-\mathrm{A}_{\text {blank }}\right)}\right] \times 100$

Here $A=$ absorbance at $595 \mathrm{~nm}$.

The highest concentrations of plant extract of $Z$. officinale which showed the non-toxicity to Vero cells were considered as their MNTD values.

\section{Determination of $50 \%$ tissue culture infectious dose}

To determine TCID $_{50}$ of CHIKV stock, $5 \times 10^{3}$ Vero cells/ well were seeded into a flat bottom 96-well plate. Plates were incubated in a $\mathrm{CO}_{2}$ incubator at $37{ }^{\circ} \mathrm{C}$ until $70-80 \%$ confluency level. Then, $100 \mu \mathrm{l}$ of ten-fold serially diluted Chikungunya virus was added to each well. Virus adsorption was done during incubation of plate in $5 \% \quad \mathrm{CO}_{2}$ humidified incubator at $37{ }^{\circ} \mathrm{C}$ for $1 \mathrm{~h} .100 \mu \mathrm{l}$ of fresh medium/wells were added to the plate and further incubated until the cytopathic effect (CPE). Negative controls (without virus) were also included. The plate was checked daily under an inverted microscope (CKX53 Olympus Corp., Japan) for CPE. After CPE was observed in the plate, TCID $_{50}$ was calculated by Reed-Muench method and viral stocks were prepared [16]. 


\section{Determination of in vitro antiviral activity of plant extract}

Anti-chikungunya activity was done with an $80 \%$ confluent Vero cell-line in 96-well plates. MNTD and half of MNTD values of $Z$. officinale extract were used for the antiviral assay. $100 \mu \mathrm{l}$ of plant extract at MNTD and half of MNTD were added in the respective wells in quadruplicates formats. In pre-treatment, plates were incubated with MNTD and half of MNTD of plant extract for $1 \mathrm{~h}$ and after that $20 \mu \mathrm{l}$ of CHIKV $\left(10^{3} \mathrm{TCID}_{50} / \mathrm{ml}\right)$ was added to each well. In co-treatment, the virus $(20 \mu \mathrm{l})$ and $100 \mu \mathrm{l}$ of plant extract were added simultaneously to their respective wells. Plates were incubated for $1 \mathrm{~h}$ at $37{ }^{\circ} \mathrm{C}$ with $5 \% \mathrm{CO}_{2}$ incubator. After proper incubation, $100 \mu$ of fresh medium was added into each well. Plates were further incubated at $37{ }^{\circ} \mathrm{C}$ with $5 \% \mathrm{CO}_{2}$ for 5 days and observed daily for CPE. The change in cell viability percentage was calculated with the help of MTT assay. Positive (CHIKV+Cells) and negative (Cells only) controls were also included along with experimental $(\mathrm{CHIKV}+$ Cells + extract) wells.

\section{Results and discussion}

\section{Preparation of aqueous extract}

About one-gram extract was obtained from an aqueous solution of fresh rhizomes of $Z$. officinale (Ginger). The plant extract was boiled for 20 min then filtered through the muslin cloth and Whatman filter paper. The obtained extract mixture was lyophilized till dried form.

\section{FT-IR result analysis}

FT-IR spectra of a lyophilized extract of Z. officinale are shown in Fig. 1. The spectrum of $Z$. officinale showed the prominent transmittance types of bands. This absorbance peak values can be compared to the standard IR spectrum available online (Table 1).

\section{Maximum non-toxic dose (MNTD) assay}

The MNTD of Z. officinale plant extract was calculated with serial dilution in the Vero cell line followed by MTT assay. The microplate reader provides the numerical value against the different concentrations of extract in respective wells. Blank and control values were recorded at 0.036 and 0.92 respectively. MNTD of $Z$. officinale plant extract in the Vero cell line was $62.5 \mu \mathrm{g} / \mathrm{ml}$.

\section{Determination of tissue culture infective dose ( TCID $_{50}$ )}

TCID $_{50}$ estimates the concentration of CHIKV which induce CPE in $50 \%$ of the cells. Under observation, the CHIKV infected cells undergo structural changes, like syncytia formation and blebbing, when seen under an inverted microscope. TCID $_{50}$ value was calculated as $10^{3}$ $\mathrm{TCID}_{50} / \mathrm{mL}$ for anti-viral assay.

\section{Determination of antiviral property of plant extract of Z. officinale}

The antiviral assay was performed to determine the antiviral effect of the aquatic extract of $Z$. officinale with the TICD $_{50}$ valve of CHIKV. Anti- CHIKV effects of $Z$. officinale extract was determined by inhibition of CPE and an increase in cell viability (Fig. 2). However, upon treating the CHIKV infected cells with plant extract of the Z. officinale with MNTD, an increase in the percentage of cell viability was observed and calculated by MTT assay. However, upon treating the CHIKV infected cells with plant extract of $Z$. officinale MNTD and half of MNTD, an increase in the percentage of cell viability was observed. Our study revealed that in pre-treatment, CHIKV infected Vero cells when treated with plant extract at MNTD and half of MNTD showed $51.05 \%$ and $35.1 \%$ increase in cell viability. Similarly, in co-treatment, plant extract at MNTD and half of MNTD brought $52.9 \%$ and $49.02 \%$ increase in cell viability, respectively (Fig. 3).

Suddenly viral outbreaks in India are increasing like pandemic Influenza [17], Nipah virus [18], Zika virus [19], dengue and Chikungunya virus is one of them. Chikungunya virus is a highly infectious viral disease and well notorious since its origin from Tanzania and has the potential to re-emerging the global level [20, 21]. There is no vaccine and antiviral for CHIKV. Chemically synthesized antivirals have a variety of side effects as compared to natural medicinal plant remedies [22].According to the Indian Ayurvedic system, Z. officinale (Ginger) is a wellknown medicinal plant and very helpful in controlling gastrointestinal problems by reducing nausea. Ginger is already utilized to treat morning sickness, heartburn, colic, stomach upset, gas, flatulence, bloating, diarrhea, loss of appetite and dyspepsia [23-25]. Ginger act as an analgesic and helpful for muscle soreness, arthritis, chest pain, stomach pain, low back pain, and menstrual pain. Ginger is a well-known medicinal plant to treat cough, respiratory tract infections, bronchitis. Fresh and dilute juice of ginger is very useful in skin burns treatment. Active components of ginger are utilized as a laxative and antacid medication. As per Ayurveda system, Ginger is well known for the treatment of a variety of cancers including skin, oral, 
Fig. 1 FTIR transmittance graph of Lyophilized $Z$. officinale extract

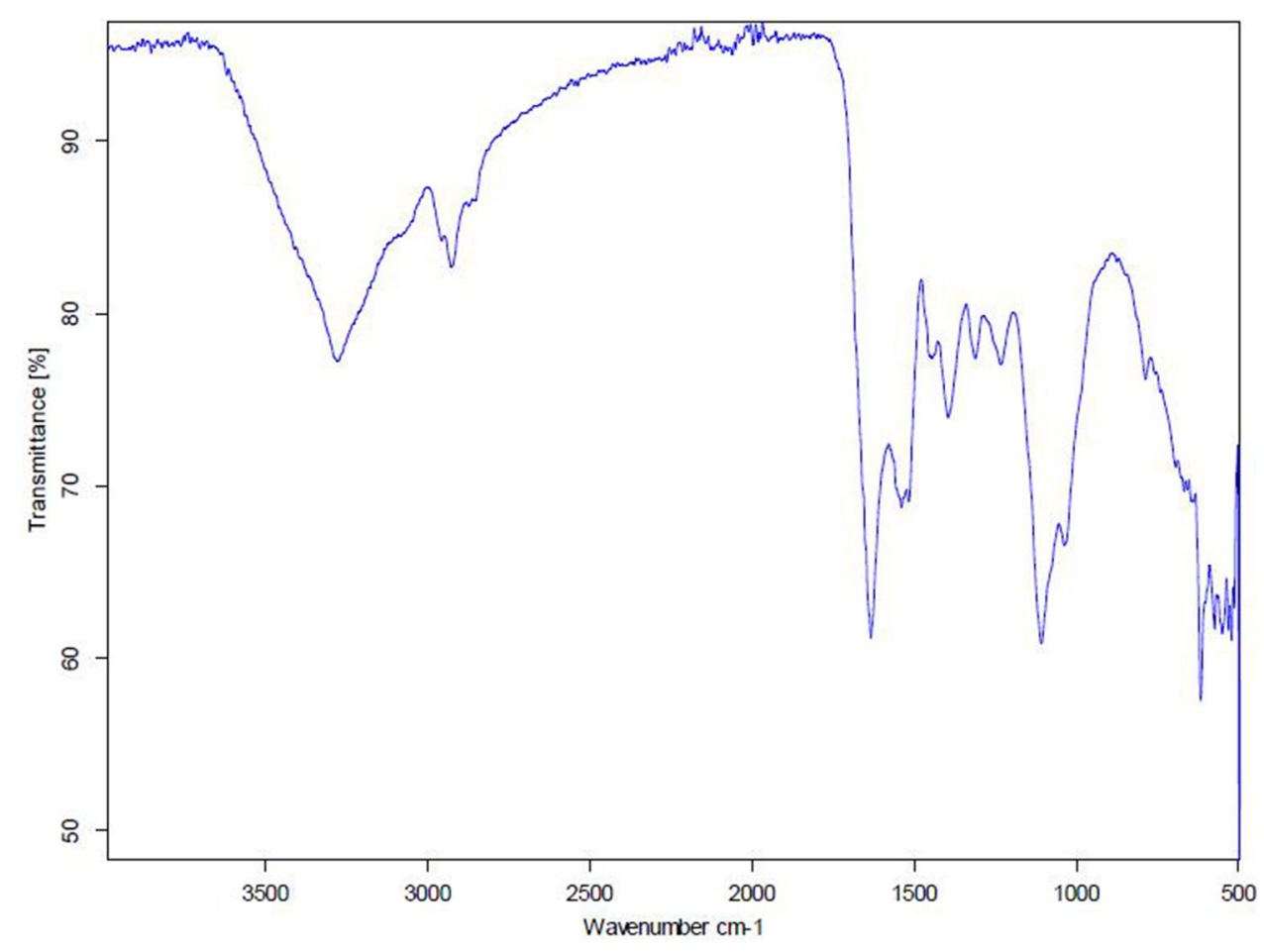

\begin{tabular}{llll}
\hline $\begin{array}{l}\text { Wavenumbers } \\
\left(\mathrm{cm}^{-1}\right)\end{array}$ & Chemical bond & Phytoconstituent & $\begin{array}{l}\text { Peaks observed } \\
\text { Plant Extract }\end{array}$ \\
\hline $3300-4000$ & $\alpha-\mathrm{CH} 3$ & Aldehydes and ketones & 3853 \\
$2500-3300$ & O-H (very broad) & Carboxylic acids & 3278 \\
$2500-3300$ & O-H (very broad) & Carboxylic acids & 2926 \\
$1900-2000$ & C=C (symmetry reduces intensity) & Alkenes & 2061 \\
$1630-1680$ & =CH2 (usually sharp) & Alkenes & 1634 \\
$1530 \pm 20$ & N=O & Nitroso compounds & 1539 \\
$1395-1440$ & C-O-H & Carboxylic acids & 1445 \\
$1395-1440$ & $\mathrm{C}-\mathrm{O}-\mathrm{H}$ & Carboxylic acids & 1395 \\
$1210-1320$ & $\mathrm{C}=\mathrm{O}$ & Carboxylic acids & 1311 \\
$1000-1250$ & $\mathrm{C}-\mathrm{N}$ & Amines & 1233 \\
$1050-1200$ & $\mathrm{C}=\mathrm{S}$ & Thio carbonyls & 1108 \\
\hline
\end{tabular}

Table 1 FT-IR spectrum of $Z$. officinale AgNPs in the region of 4000-500 cm-1 breast, liver, gastric, pancreatic, colon, renal, prostate, brain, ovarian and cervical cancer. Ginger has antioxidant, anti-inflammatory and anti-mutagenic properties [26].

The present study has been conceptualized to check the anti-chikungunya activity of aquatic plant extract from the rhizome of $Z$. officinale. The anti-chikungunya effect of $Z$. officinale plant extract was checked in vitro model by using a Vero cell-line. In- vitro assessment of maximum nontoxic dose of aquatic medicinal of plant extract are crucial before their therapeutic uses to the possibilities of their side-effects. Cytotoxicity of aquatic medicinal plant extract was observed on the Vero cell-line in terms of cytopathic effect. In present study, MNTD of $Z$. officinale aquatic plant extract was found to be $62.50 \mu \mathrm{g} / \mathrm{mL}$.

Anti-chikungunya effects of the medicinal plant extract were determined on Vero cell with MNTD and half of MNTD through pre- and co-treating mode of treatment. The results point out that the aquatic plant extract of $Z$. officinale has anti-chikungunya potential. Antiviral assays were performed to study the effect of plant extract, they may hamper the CHIKV replication in Vero cell-line. Our study revealed that Vero cells when pre-treated with MNTD and half of MNTD of Z. officinale plant extract, their viability increase $51.05 \%$ and $35.1 \%$ respectively. Vero cell viability increases $52.9 \%$ and $49.02 \%$ when co- 

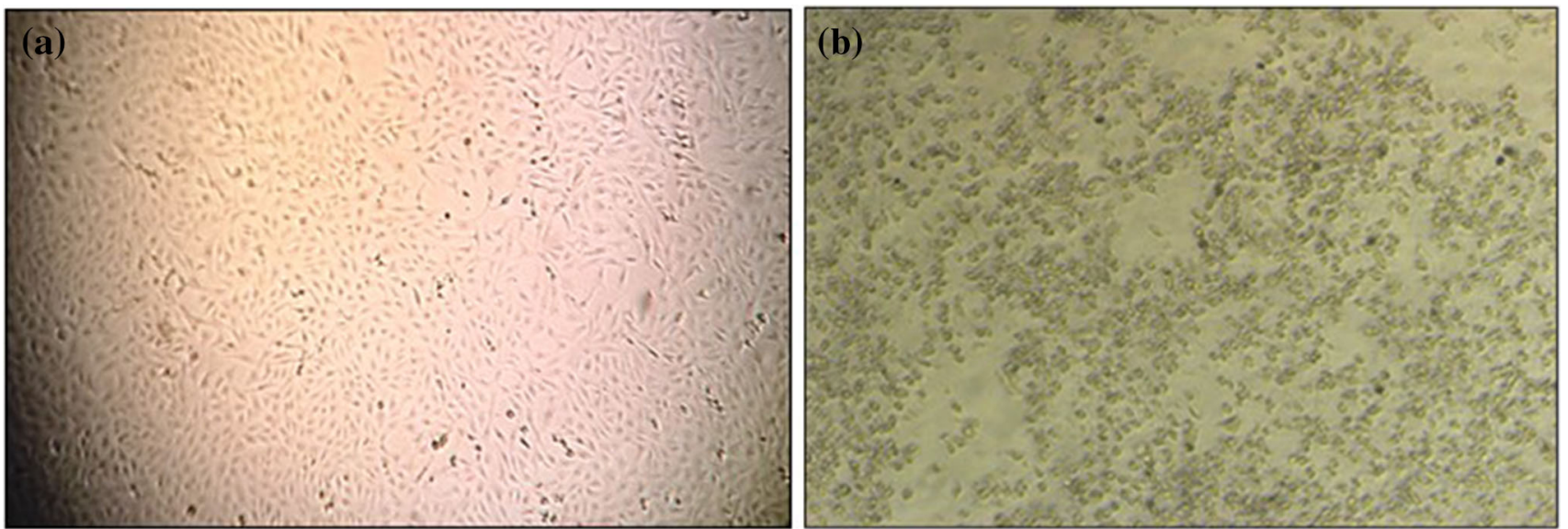

Fig. 2 Cytopathic effects of CHIKV (a) Normal cells (b) virus infected Vero cells

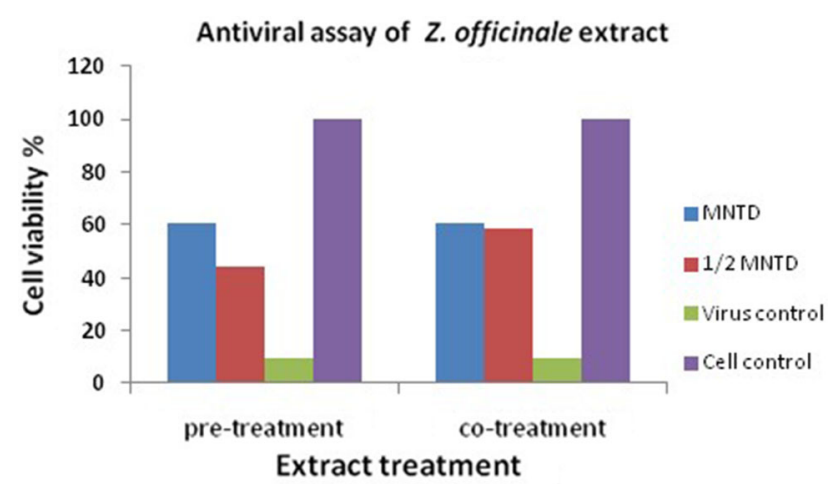

Fig. 3 Antiviral effect of plant extract of the Z. officinale on CHIKV in Vero cells

treatment with MNTD and half of MNTD Z. officinale plant extract.

Medicinal plants and their secondary metabolites have therapeutic potential against other similar viruses like dengue [27]. Although C. papaya leaves are generally taken during dengue fever, $C$. papaya may not interfere with viral replication but responsible for increasing the platelets [28, 29]. In previous other similar studied on andrographolide show anti-chikungunya potential when a study in the HepG2 cell-line [30]. In another study, plant extract and their AgNPs of $T$. cordifolia, have the potential to interfere with CHIKV and able to increase the $75 \%$ and $56 \%$ Vero viability when these cells were treated MNTD and half of MNTD, respectively. Medicinal plants are very sensitive, specific and cost-effective against various old and emerging viruses. In another similar study on influenza virus, aqueous Isatidis Radix extract were screening for the anti-influenza property in Madin-Darby Canine Kidney (MDCK) cells, less influenza viruses were observed by scanning electron microscope (SEM) in the Isatidis Radix extract pre-treated cells than the cells without Isatidis
Radix extract treatment [31]. Despite the huge immunization and modern medication, many viruses lack preventive vaccines and effective antiviral therapies. In the situation, identification of novel antiviral drugs from medicinal plants are more importance as natural products are an excellent source and safer. Medicinal plants are good source of antiviral and effective herbal medicines [32].

Medicinal plants compounds have antibacterial [33-35] and anticancer [36] properties. Antiviral activities of medicinal plants have been reported against various medically important viruses including, vaccinia virus, HSV, RSV, FLU, MPU, HIV and HBV [37-45]. Medicinal plants could interfere with viral replication through various mechanisms. It is reported that components from certain medicinal plants, interfere with the binding of viron to the cellular receptors, therefore can avoid their entrance in the cell. The exact mechanism of medicinal plants for their antiviral actions has not been fully understood. Therefore, the interaction of medicinal plant extracts with different types of cells is a complex phenomenon that requires further details study.

In conclusion, aquatic medicinal plant extract successfully manufactures the from the fresh rhizome of $Z$. officinale. The aquatic plant extract of $Z$. officinale showed excellent anti-chikungunya activity. A large number of compounds may involve in combating the CHIKV. Plant extracts are comparatively simple, capable, economical and an environment-friendly as compared to the chemically synthesized drugs. Medicinal plants could be an alternative source to develop a wide range of antiviral agents which could very helpful the alternative treatment of viruses. Zingiber officinale not only has a therapeutic potential but also combat drug resistance in antivirals against CHIKV. It is advisable, before using aquatic plant extract or their nano-material as therapeutic agents in the form of antiviral, 
their toxicity or side-effects and molecular mechanism should be studied properly.

Acknowledgements Sulochana Kaushik, Yashika Sharma and Divya Dhull acknowledges their financial supports received from Maharshi Dayanand University, Rohtak for the award of University Research Scholarship to them.

Funding This research did not receive any specific grant from funding agencies in the public, commercial, or not-for-profit sectors.

\section{Compliance with ethical standards}

Conflict of interest The authors declare that they have no conflict of interest.

\section{References}

1. Schwartz O, Albert ML. Biology and pathogenesis of chikungunya virus. Nat Rev Microbiol. 2010; 8:491-500. https://www. ncbi.nlm.nih.gov/pubmed/20551973.

2. Benelli G. Commentary: data analysis in bionanoscience-issues to watch for. J Cluster Sci. 2017; 28; 1:11-4. https://link.springer. com/article/10.1007/s10876-016-1143-3

3. Tsetsarkin KA, Vanlandingham DL, McGee CE, Higgs S. A single mutation in chikungunya virus affects vector specificity and epidemic potential. PLoS Pathog. 2007; 3:12 https://www. ncbi.nlm.nih.gov/pmc/articles/PMC2134949/

4. Monteiro VV, Navegantes-Lima KC, de Lemos AB, Da Silva GL, de Souza Gomes R, Reis JF, Junior LC, da Silva OS, Romão PR, Monteiro MC. Aedes-Chikungunya Virus Interaction: Key Role of Vector Midguts Microbiota and Its Saliva in the Host Infection. Front. Microbiol. 2019; 10. doi: 10.3389/ fmicb.2019.00492

5. Jain J, Kumar A, Narayanan V, Ramaswamy RS, Sathiyarajeswaran P, Devi MS, Kannan M, Sunil S. Antiviral activity of ethanolic extract of Nilavembu Kudineer against dengue and chikungunya virus through in vitro evaluation. J Ayurveda Integr Med. 2019. https://doi.org/10.1016/j.jaim.2018.05.006.

6. NIAID https://www.niaid.nih.gov/research/emerging-infectiousdiseases-pathogens Accessed 20 May 2019

7. Mehta R, Gerardin P, de Brito CA, Soares CN, Ferreira ML, Solomon T. The neurological complications of chikungunya virus: a systematic review. Rev Med Virol. 2018;28:e1978. https://doi.org/10.1002/rmv.1978.

8. Thiberville SD, Moyen N, Dupuis-Maguiraga L, Nougairede A, Gould EA, Roques P, de Lamballerie X. Chikungunya fever: epidemiology, clinical syndrome, pathogenesis and therapy. Antiviral Res. 2013;99:345-70. https://doi.org/10.1016/j.anti viral.2013.06.009.

9. Sharma V, Kaushik S, Pandit P, Dhull D, Yadav JP, Kaushik S. Green synthesis of silver nanoparticles from medicinal plants and evaluation of their antiviral potential against chikungunya virus. Appl Microbiol Biotechnol. 2019;103:881-91. https://doi.org/10. 1007/s00253-018-9488-1.

10. Esposito M, Nothias LF, Nedev H, Gallard JF, Leyssen P, Retailleau P, Costa J, Roussi F, Iorga BI, Paolini J, Litaudon M. Euphorbia dendroides Latex as a source of jatrophane esters: isolation, structural analysis, conformational study, and antiCHIKV activity. J Nat Prod. 2016;79:2873-82. https://doi.org/10. 1021/acs.jnatprod.6b00644.

11. Murali KS, Sivasubramanian S, Vincent S, Murugan SB, Giridaran B, Dinesh S, Gunasekaran P, Krishnasamy K,
Sathishkumar R. Anti-chikungunya activity of luteolin and apigenin rich fraction from Cynodon dactylon. Asian Pac J Trop Med. 2015;8:352-8. https://doi.org/10.1016/S1995-7645(14) 60343-6.

12. Frederico ÉH, Cardoso AL, Moreira-Marconi E, de Sá-Caputo DD, Guimarães CA, da Fontoura DC, Morel DS, PaineirasDomingos LL, de Souza PL, Brandão-Sobrinho-Neto S, Carvalho-Lima RP. Anti-viral effects of medicinal plants in the management of dengue: a systematic review. Afr J Tradit Complement Altern Med. 2017;14(4S):33-40.

13. Bode AM, Dong Z. The Amazing and Mighty Ginger. In: Benzie IFF, Wachtel-Galor S, editors. Herbal Medicine: Biomolecular and Clinical Aspects. 2nd edition. Boca Raton (FL): CRC Press/ Taylor \& Francis; 2011. Chapter 7. Available from: https://www. ncbi.nlm.nih.gov/books/NBK92775/

14. Ansari JA, Ahmad MK, Khan AR, Fatima N, Khan HJ, Rastogi N, Mishra DP, Mahdi AA. Anticancer and antioxidant activity of Zingiber officinale Roscoe rhizome. Indian $\mathrm{J}$ Exp Biol. 2016;54:767-73.

15. Elkady AI, Abu-Zinadah OA, Hussein RA. Crude flavonoid extract of medicinal herb Zingibar officinale inhibits proliferation and induces apoptosis in hepatocellular carcinoma cells. Oncol Res Featuring Preclinical Clin Cancer Ther. 2017;25(6):897-912. https://doi.org/10.3727/096504016X14816352324532.

16. Reed LJ, Muench H. A simple method of estimating fifty per cent endpoints. Am J Epidemiol. 1938;27:493-7.

17. Broor S, Gupta S, Mohapatra S, Kaushik S, Mir MA, Jain P, Dar L, Lal RB. Emergence of 2009A/H1N1 cases in a tertiary care hospital in New Delhi, India. Influenza Other Respir Viruses. 2009A;5(6):e552-e55757. https://doi.org/10.1111/j.1750-2659. 2011.00274.x.

18. Sharma V, Kaushik S, Kumar R, Yadav JP, Kaushik S. Emerging trends of Nipah virus: a review. Rev Med Virol. 2019;29:e2010. https://doi.org/10.1002/rmv.2010.

19. Sharma V, Sharma M, Dhull D, Sharma Y, Kaushik S, Kaushik S. Zika virus: an emerging challenge to public health worldwide. Can J Microbiol. 2020;66:87-988. https://doi.org/10.1139/cjm2019-0331.

20. Robinson MC. An epidemic of virus disease in Southern Province, Tanganyika territory, in 1952-1953. Trans R Soc Trop Med Hyg. 1955;49:28-322.

21. Murugan SB, Sathishkumar R. Chikungunya infection: a potential re-emerging global threat. Asian Pac J Trop Med. 2016;9:933-7. https://doi.org/10.1016/j.apjtm.2016.07.020.

22. Müller V, Chávez JH, Reginatto FH, Zucolotto SM, Niero R, Navarro D, Yunes RA, Schenkel EP, Barardi CR, Zanetti CR, Simões CM. Evaluation of antiviral activity of South American plant extracts against herpes simplex virus type 1 and rabies virus. Phytother Res. 2007;21:970-4. https://doi.org/10.1002/ptr. 2198.

23. Yamahara J, Huang Q, LI Y, XU L, Fujimura H. Gastrointestinal motility enhancing effect of ginger and its active constituents. Chem Pharm Bull. 1990; 38:430-1.

24. Mowrey D, Clayson D. Motion sickness, ginger, and psychophysics. The Lancet. 1982;319(8273):655-7.

25. Stewart JJ, Wood MJ, Wood CD, Mims ME. Effects of ginger on motion sickness susceptibility and gastric function. Pharmacology. 1991;42:111-20. https://doi.org/10.1159/000138781.

26. Srinivasan K. Antioxidant potential of spices and their active constituents. Crit Rev Food Sci Nutr. 2014;54:352-72. https:// doi.org/10.1080/10408398.2011.585525.

27. Liu W, Wu Y, Wang C, Li HC, Wang T, Liao CY, Cui L, Zhou QF, Yan B, Jiang GB. Impact of silver nanoparticles on human cells: effect of particle size. Nanotoxicology. 2010;4:319-30. https://doi.org/10.3109/17435390.2010.483745. 
28. Kaushik S, Kaushik S, Sharma V, Yadav J. Antiviral and therapeutic uses of medicinal plants and their derivatives against dengue viruses. Phcog Rev. 2018;12:177-85. https://doi.org/10. 4103/phrev.phrev_2_18.

29. Kaushik S, Sharma V, Chhikara S, Yadav JP, Kaushik S. Antichikungunya activity of green synthesized silver nanoparticles using Carica Papaya leaves in animal cell culture model. Asian J Pharm Clin Res. 2019;12:170-4.

30. Wintachai P, Kaur P, Lee RC, Ramphan S, Kuadkitkan A, Wikan N, Ubol S, Roytrakul S, Chu JJ, Smith DR. Activity of andrographolide against chikungunya virus infection. Sci Rep. 2015;5:14179. https://doi.org/10.1038/srep14179.

31. Ke L, Wen T, Bradshaw JP, Zhou J, Rao P. Antiviral decoction of isatidis radix (板藍根 băn lán gēn) inhibited influenza virus adsorption on MDCK cells by cytoprotective activity. J Tradit Complement Med. 2012;2(1):47-51. https://doi.org/10.1016/ S2225-4110(16)30070-0.

32. Lin LT, Hsu WC, Lin CC. Antiviral natural products and herbal medicines. J Tradit Complement Med. 2014;4:24-35. https://doi. org/10.4103/2225-4110.124335.

33. Abuga I, Sulaiman SF, Wahab RA, Ooi KL, Rasad MS. In vitro antibacterial effect of the leaf extract of Murraya koenigii on cell membrane destruction against pathogenic bacteria and phenolic compounds identification. Eur J Integr Med. 2020;33:101010. https://doi.org/10.1016/j.eujim.2019.101010.

34. Chacón O, Forno N, Lapierre L, Muñoz R, Fresno M, San MB. Effect of Aloe barbadensis Miller (Aloe vera) associated with beta-lactam antibiotics on the occurrence of resistance in strains of Staphylococcus aureus and Streptococcus uberis. Eur J Integr Med. 2019;32:100996. https://doi.org/10.1016/j.eujim.2019. 100996.

35. Liu C, Huang H, Zhou Q, Liu B, Wang Y, Li P, Liao K, Su W. Antibacterial and antibiotic synergistic activities of the extract from Pithecellobium clypearia against clinically important multidrug-resistant gram-negative bacteria. Eur J Integr Med. 2019;32:100999. https://doi.org/10.1016/j.eujim.2019.100999.

36. Sharma A, Sharma P, Singh S, Karegoudar TB, Holla H. Evaluation of leaves of Goniothalamus wynaadensis Bedd. for inhibition of metabolic viability of cancer cells \& antimicrobial efficacy. Eur J Integr Med. 2019;32:101000. https://doi.org/10. 1016/j.eujim.2019.101000.
37. Rogers JV, Parkinson CV, Choi YW, Speshock JL, Hussain SM. A preliminary assessment of silver nanoparticle inhibition of monkeypox virus plaque formation. Nanoscale Res Lett. 2008;3:129-33.

38. Lara HH, Ayala-Nuñez NV, Ixtepan-Turrent L, RodriguezPadilla C. Mode of antiviral action of silver nanoparticles against HIV-1. J Nanobiotechnol. 2010;8:1. https://doi.org/10.1186/ 1477-55-8-1.

39. Galdiero S, Falanga A, Vitiello M, Cantisani M, Marra V, Galdiero M. Silver nanoparticles as potential antiviral agents. Molecules. 2011;16(10):8894-918. https://doi.org/10.3390/ molecules16108894.

40. Mori Y, Ono T, Miyahira Y, Nguyen VQ, Matsui T, Ishihara M. Antiviral activity of silver nanoparticle/chitosan composites against H1N1 influenza A virus. Nanoscale Res Lett. 2013;8:93.

41. Trefry JC, Wooley DP. Silver nanoparticles inhibit vaccinia virus infection by preventing viral entry through a macropinocytosisdependent mechanism. J Biomed Nanotechnol. 2013;9:1624-35. https://doi.org/10.1166/jbn.2013.1659.

42. Hu RL, Li SR, Kong FJ, Hou RJ, Guan XL, Guo F. Inhibition effect of silver nanoparticles on herpes simplex virus 2 . Genet Mol Res. 2014;13:7022-8.

43. Yang $\mathrm{XX}, \mathrm{Li} \mathrm{CM}$, Huang CZ. Curcumin modified silver nanoparticles for highly efficient inhibition of respiratory syncytial virus infection. Nanoscale. 2016;8:3040-8. https://doi.org/ 10.1039/C5NR07918G.

44. Shevtsov M, Zhao L, Protzer U, Klundert M. Applicability of metal nanoparticles in the detection and monitoring of hepatitis B virus infection. Viruses. 2017;9:193. https://doi.org/10.3390/ v9070193.

45. Sornpet B, Potha T, Tragoolpua Y, Pringproa K. Antiviral activity of five Asian medicinal pant crude extracts against highly pathogenic H5N1 avian influenza virus. Asian Pac J Trop Med. 2017;10:871-6. https://doi.org/10.1016/j.apjtm.2017.08.010.

\section{Publisher's Note}

Springer Nature remains neutral with regard to jurisdictional claims in published maps and institutional affiliations. 